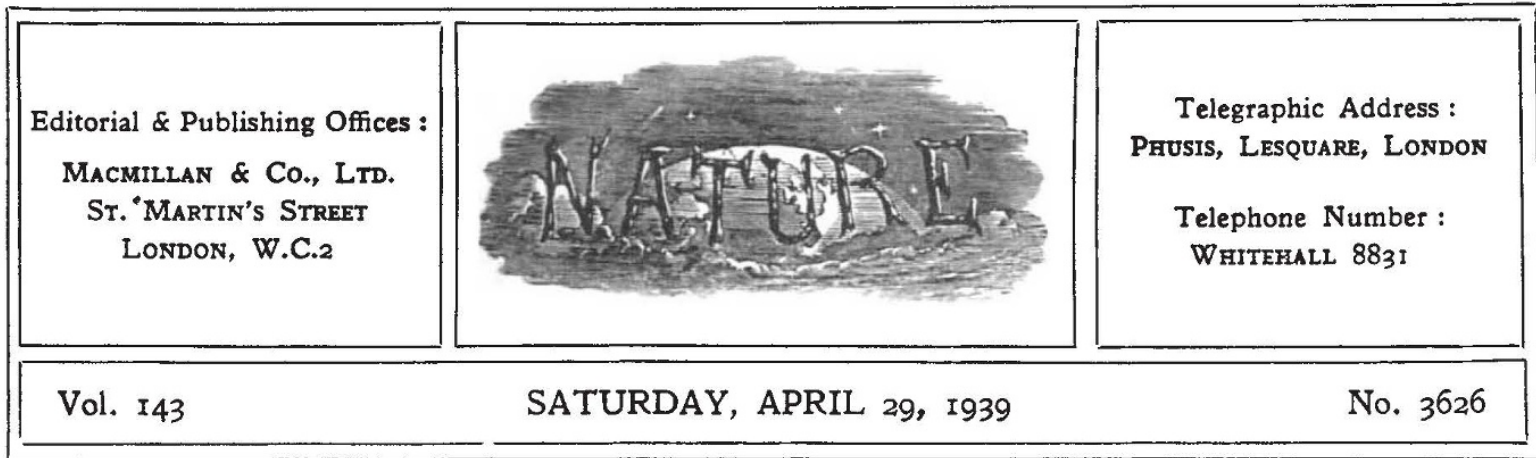

\title{
Aeronautical Research in Australia
}

$\mathrm{E}^{\mathrm{A}}$ ARLY in 1937 the Australian Government invited Mr. H. E. Wimperis to advise on the inauguration of aeronautical research in the Australian Commonwealth. It could have made no better choice. Mr. Wimperis has been closely connected with aeronautical research practically from its beginnings in Great Britain. For twelve years until he retired in 1937 he was responsible, as director of scientific research, for the organization and development of research in the Air Ministry. Owing to his retirement he was free to apply his unrivalled experience to the problems of Australia. He spent six months in visiting the Royal Australian Air Force Stations in New South Wales, Victoria, and Western Australia, and the civil aerodromes in New South Wales, Victoria, Western Australia and Brisbane. He also visited the Munitions Supply Establishment at Maribyrnong, Victoria, and many engineering and industrial plants.

One of the principal recommendations made by Mr. Wimperis in his report* is that an engineering research establishment be organized for experimental work in aerodynamics, aircraft and automobile engines, and for the testing and development of aircraft instruments and other equipment. $\mathrm{Mr}$. Wimperis estimates the initial capital cost of such an establishment to be $£ 143,000$, and the annual cost of its staff when completed to be of the order of $£ 12,000$ a year.

This recommendation has already been acted upon, and a start has been made in the building of the laboratory at Fishermen's Bend, a few miles from Melbourne. The laboratory is to be built close by the aerodrome belonging to the independent Commonwealth Aircraft Corporation,

* Parliament of the Commonwealth of Australia. Report by $\mathbf{H}$. $\mathbf{E}$. Wimperis on the Inauguration of Aeronautical Research in Australia, dated 21st December 1937. Pp. 17. (Canberra: Government Printer, 1938.) 18 . which has agreed to give free use of its aerodrome to the laboratory and to co-operate fully with the research investigations. A short distance away are the works of the General Motors Company.

It is understood that the Commonwealth Government also intends to set up a Bureau of Standards at Sydney. The new Engineering Research Laboratory at Fishermen's Bend and the Bureau of Standards at Sydney will correspond together to the National Physical Laboratory in England. The aeronautical work at the new laboratory will be supervised by an Australian Aeronautical Research Committee; but the laboratory as a whole will be administered by the Council for Scientific and Industrial Research, the chief executive officer of which is Sir David Rivett.

Mr. Wimperis also recommends the establishment of a professorship of aeronautical engineering, and a readership in meteorology in Australian universities. Both these recommendations have already been given effect. A chair of aeronautical engineering has been established at the University of Sydney. The Commonwealth Government has made a grant of $£ 20,000$ for the building of an aerodynamics laboratory at the University, $£ 12,000$ for its equipment, and $£ 3,000$ a year for salaries and maintenance. The State Government has added $£ 18,000$ for building a hydrodynamics laboratory in conjunction with the aerodynamics laboratory. An assistant professorship of meteorology has been established at the University of Melbourne.

It may possibly be argued that the comparative remoteness of Australia, even in these days of rapid transport, the smallness of its population, and the relatively insignificant size of its industry, all combine to make the carrying out of aeronautical research both expensive and unnecessary, in view of the very large sums of money already 
devoted to the subject in other countries in Europe and America. Would it not be possible for Australia to get all the information it needs by studying the results of work in Great Britain and in America without attempting to duplicate it on what would appear in these countries to be an inadequate scale? Such views have been expressed, but we believe them to be entirely wrong. In the first place, no one can appreciate fully and apply the results of scientific investigations unless they themselves are engaged on similar work. It does not matter in the least that Australia may not be in a position for many years to contribute anything of first-class importance to the science of aeronautics. If no start is made, there never will be such contributions. Now that the start has been made, Australian contributions to the science will depend upon whether men of first-rate ability can be attracted to the country. In the meantime, the presence and active work of a trained staff will undoubtedly lead to a fuller comprehension and application of the results of work in other countries.

In the second place, Australia is committed to a policy of developing its manufacturing industries, as well as the older and more valuable industries of agriculture and mining. If Australia seeks, as it undoubtedly does, to attain a high state of efficiency in its manufacturing industries, it certainly needs a central institution of the first rank in engineering research. In the particular case of the aeronautical industry, it is essential for the defence of Australia, and not merely of Australia but also of the British Commonwealth of Nations, that the manufacture of aircraft on a large scale should be undertaken in Australia. A start has been made and the industry is in the hands of capable and enthusiastic leaders. That it is bound to expand, and expand very greatly, in the near future is scarcely open to doubt, and its expansion must be facilitated by the now cration of a Government Aeronautical Research Laboratory. In aeronautics, as in every other branch of applied science, research and manufacture react on each other. Neither can be fully efficient unless it is in close contact with the other. Aircraft manufacture in Australia cannot exist in a healthy state if it merely relies on information and advice from other countries; nor will Australian aeronautical research be much more than academic and second rate if it is not carried out in the closest contact and with the enthusiastic support of Australian aircraft manufacturers.

The organization starts under the happiest auspices. The Australian Council for Scientific and Industrial Research, presided over by Sir George Julius, and administered by Sir David Rivett, has the complete confidence of the Australian Government, and scientific workers in Great Britain as well as those in Australia will feel that the development of aeronautical research in that continent is in safe hands.

\section{The Modern Approach to Indian Problems}

(I) Social Service in India :

an Introduction to some Social and Economic Problems of the Indian People. Written by Six Contributors. Edited by Sir Edward Blunt. Pp. xxiii $+447+16$ plates. (London: H.M. Stationery Office, 1938.) 10s. $6 d$. net.

(2) Health and Nutrition in India

By N. Gangulee. Pp. viii $+337+13$ plates. (London: Faber and Faber, Ltd., 1939.) 15s. net.

(1) WHATEVER may have been the ideas of the founders of the British Empire, the purpose always before the best of the modern administrators is to develop each part so as to give to its inhabitants the fullest and richest life possible for them. This purpose is particularly clearly shown in the volume called, appropriately enough, "Social Service in India" published by
H.M. Stationery Office, and edited by Sir Edward Blunt, with the collaboration of six colleagues, including some of the most distinguished Indian civil servants. The volume grew out of a proposal made by Sir eAtul C. Chatterjee's Committee set up in 1936 to inquire into the system of probation for the Indian Civil Service : the proposal was that lectures should be given to the probationers on social welfare in India, and that a book should be prepared for use in connexion therewith. The first course was given in 1938 and the chapters were issued in typescript ; they were then revised and expanded and are now printed in book form.

Contributors and editors alike have done their work well, and we know of no account of modern India so complete and concise as this. Sir Edward opens with two chapters on the environment and the people, showing, in the manner of the modern 